\title{
Statistical Study for Leaching of Covellite in a Chloride Media
}

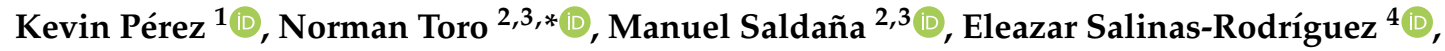 \\ Pedro Robles ${ }^{5}$, David Torres ${ }^{2,6}$ and Ricardo I. Jeldres ${ }^{1, * \mathbb{D}}$ \\ 1 Departamento de Ingeniería Química y Procesos de Minerales, Universidad de Antofagasta, \\ Antofagasta 1270300, Chile; kps003@alumnos.ucn.cl \\ 2 Faculty of Engineering and Architecture, Universidad Arturo Prat, Almirante Juan José Latorre 2901, \\ Antofagasta 1244260, Chile; manuel.saldana@ucn.cl (M.S.); david.Torres@sqm.com (D.T.) \\ 3 Departamento de Ingeniería Metalúrgica y Minas, Universidad Católica del Norte, \\ Antofagasta 1270709, Chile \\ 4 Área Académica de Ciencias de la Tierra y Materiales, Universidad Autónoma del Estado de Hidalgo, \\ Carretera Pachuca-Tulancingo km. 4.5, C.P. 42184, Mineral de la Reforma, Hidalgo C.P. 42184, Mexico; \\ salinasr@uaeh.edu.mx \\ 5 Escuela de Ingeniería Química, Pontificia Universidad Católica de Valparaíso, Valparaíso 2340000, Chile; \\ pedro.robles@pucv.cl \\ 6 Department of Mining, Geological and Cartographic Department, Universidad Politécnica de Cartagena, \\ 30203 Murcia, Spain \\ * Correspondence: ntoro@ucn.cl (N.T.); ricardo.jeldres@uantof.cl (R.I.J.); Tel.: +56-55-2651-021 (N.T.)
}

Received: 23 March 2020; Accepted: 3 April 2020; Published: 4 April 2020

\begin{abstract}
Covellite is a secondary copper sulfide, and it is not abundant. There are few investigations on this mineral in spite of it being formed during the leaching of chalcocite or digenite; the other investigations on covellite are with the use of mineraloids, copper concentrates, and synthetic covellite. The present investigation applied the surface optimization methodology using a central composite face design to evaluate the effect of leaching time, chloride concentration, and sulfuric acid concentration on the level of copper extraction from covellite ( $84.3 \%$ of purity). Copper is dissolved from a sample of pure covellite without the application of temperature or pressure; the importance of its purity is that the behavior of the parameters is analyzed, isolating the impurities that affect leaching. The chloride came from $\mathrm{NaCl}$, and it was effectuated in a size range from -150 to $+106 \mu \mathrm{m}$. An ANOVA indicated that the leaching time and chloride concentration have the most significant influence, while the copper extraction was independent of sulfuric acid concentration. The experimental data were described by a highly representative quadratic model obtained by linear regression $\left(R^{2}=0.99\right)$.
\end{abstract}

Keywords: sulfide leaching; ANOVA; secondary sulfide; CuS

\section{Introduction}

Covellite is not an abundant, but it may be found in many copper deposits as a supergenic mineral, usually as a coating in the sulfide enrichment zone. It is associated with the derivation due to alteration from other minerals, such as chalcocite, chalcopyrite, bornite, and enargite [1]. Covellite appears in attractive proportion in the oxidized minerals; it is an intermediate product for the conversion of chalcopyrite [2] and participates in transforming digenite to covellite in oxygenated media [3,4].

Sulfurized copper ores are generally treated by flotation-smelting-refining [5-7]. Although they have reported economic [8] and metallurgical viability, there are environmental problems associated with the emission of sulfur dioxide and arsenic [9-13]. Arsenic, which has continuously increased in recent decades with the increasing extraction of copper sulfide [14], presents a risk to human health 
associated with a higher incidence of cancer and cardiovascular and respiratory diseases [15]. This has led to increasingly stringent environmental controls. In contrast, the recovery of complex low-grade copper minerals is based on the hydrometallurgical method, which is preferred due to its low cost of treatment, short construction time, operational simplicity, and functional recovery performance [16]. Additionally, this strategy has environmental benefits by producing non-hazardous solid waste [17-19].

Sulfuric acid and an oxidizing agent are required to break down sulfurized copper ores and release $\mathrm{Cu}^{2+}$ in solution. All copper sulfides require the presence of $\mathrm{Fe}^{3+}$ and $\mathrm{O}_{2}$ as oxidizing agents for leaching to occur. Copper sulfide is oxidized by the presence of $\mathrm{Fe}^{3+}$, and the resulting $\mathrm{Fe}^{2+}$ is reoxidized to $\mathrm{Fe}^{3+}$ by $\mathrm{O}_{2}$. The redox pair $\mathrm{Fe}^{2+} / \mathrm{Fe}^{3+}$ act as a catalyst in these reactions. The following reactions occur with the main secondary copper mineral, chalcocite, when the temperature is high (Equation (1)), and the sulfur is in the form of sulfate and not of elemental sulfur, as in natural conditions (Equations (2) and (3)) [5]:

$$
\begin{gathered}
\mathrm{Cu}_{2} \mathrm{~S}_{(\mathrm{s})}+\mathrm{Fe}_{2}\left(\mathrm{SO}_{4}\right)_{3(\mathrm{aq})}=\mathrm{Cu}^{2+}{ }_{(\mathrm{aq})}+\mathrm{SO}_{4}{ }^{2-}{ }_{(\mathrm{aq})}+\mathrm{CuS}_{(\mathrm{s})}+2 \mathrm{FeSO}_{4(\mathrm{aq})} \\
\mathrm{Cu}_{2} \mathrm{~S}_{(\mathrm{s})}+2 \mathrm{Fe}^{3+}{ }_{(\mathrm{aq})}=\mathrm{Cu}^{2+}{ }_{(\mathrm{aq})}+2 \mathrm{Fe}^{2+}{ }_{(\mathrm{aq})} \\
\mathrm{CuS}_{(\mathrm{s})}+2 \mathrm{Fe}^{3+}{ }_{(\mathrm{aq})}=\mathrm{Cu}^{2+}{ }_{(\mathrm{aq})}+2 \mathrm{Fe}^{2+}{ }_{(\mathrm{aq})}+\mathrm{S}^{0}{ }_{(\mathrm{s})}
\end{gathered}
$$

Research studies on covellite leaching have been varied, evaluating alternatives that contemplate different dissolution media, such as ammonia [16,20], nitrates [21,22], and chlorides [4,23-25]. Bioleaching has also been considered, including bacteria such as thiobacillus ferrooxidans, acidithiobacillus ferrooxidans, and acidithiobacillus thiooxidans, which can grow under anaerobic conditions where ferric ions are used as electron receptors [26-29].

Several researchers [23,24,30-32] have reported two phases in which copper dissolves from chalcocite in a sulfate or chloride media:

$$
\begin{gathered}
\mathrm{Cu}_{2} \mathrm{~S}_{(\mathrm{s})}+2 \mathrm{Fe}^{3+}{ }_{(\mathrm{aq})}=\mathrm{Cu}^{2+}{ }_{(\mathrm{aq})}+\mathrm{CuS}_{(\mathrm{s})}+2 \mathrm{Fe}^{2+}{ }_{(\mathrm{aq})} \\
\mathrm{CuS}_{(\mathrm{s})}+2 \mathrm{Fe}^{3+}{ }_{(\mathrm{aq})}=\mathrm{Cu}^{2+}{ }_{(\mathrm{aq})}+\mathrm{S}^{0}{ }_{(\mathrm{s})}+2 \mathrm{Fe}^{2+}{ }_{(\mathrm{aq})}
\end{gathered}
$$

According to Niu et al. [30], the leaching from chalcocite to covellite is fast (Equation (4)) because of its low activation energy ( $4-25 \mathrm{~kJ} / \mathrm{mol})$; then, the reaction is controlled by the effect diffusive of an oxidant on the mineral surface. Otherwise, the stage expressed in Equation (5), which corresponds to the transformation of covelline to dissolved copper, is slower and requires an activation energy close to $72 \mathrm{~kJ} / \mathrm{mol}$, suggesting electrochemical control [24,33]. Nicol and Basson [25] indicated that the oxidation of covellite occurs as an intermediate stage in which it is transformed into polysulfide $\mathrm{CuS}_{2}$ :

$$
\begin{aligned}
\mathrm{Cu}_{2} \mathrm{~S}_{2(\mathrm{~s})} & =\mathrm{CuS}_{2(\mathrm{~s})}+\mathrm{Cu}^{2+}{ }_{(\mathrm{aq})}+2 \mathrm{e}^{-} \\
\mathrm{CuS}_{2(\mathrm{~s})} & =\mathrm{Cu}^{2+}{ }_{(\mathrm{aq})}+2 \mathrm{~S}^{0}{ }_{(\mathrm{s})}+2 \mathrm{e}^{-}
\end{aligned}
$$

Covellite can be oxidized over a wide range of chloride concentrations and electrochemical potential; however, the subsequent oxidation of $\mathrm{CuS}_{2}$ is only achieved from media with high chloride concentrations or high potentials [25]. Copper leaching processes in a chloride media are especially adequate for leaching non-ferrous minerals such as chalcocite, djurleite, digenite, and covellite, since in these cases, the leaching solutions contain low levels of dissolved iron [3].

The expected general reaction to predict copper dissolution under the conditions described is:

$$
4 \mathrm{CuS}_{(\mathrm{s})}+8 \mathrm{Cl}^{-}{ }_{(\mathrm{aq})}+4 \mathrm{H}^{+}{ }_{(\mathrm{aq})}+\mathrm{O}_{2(\mathrm{~g})}=4 \mathrm{CuCl}_{2(\mathrm{aq})}^{-}+2 \mathrm{H}_{2} \mathrm{O}_{(\mathrm{l})}+4 \mathrm{~S}_{(\mathrm{s})}^{0} .
$$

In previous research on covellite leaching carried out by other authors, the common factor is that it was carried out with a synthetic covellite (a mineraloid), whereas the covellite used in this article is pure, coming from a mine and manually separated from impurities. The creation of synthetic covellite 
is from a stoichiometric mixture of high-purity copper and elemental sulfur, with the application of high temperature and vacuum sealing over long periods (approximately 3 days) for its formation. Investigations such as those of Cheng and Lawson [23] and Miki et al. [24] feature examples of synthetic covellite experiments (see Table 1). Meanwhile, other copper sulfide leaching investigations have been carried out with concentrates high in chalcopyrite, enargite, digenite, and chalcocite, among others, such as for example the investigations by Lundstrom [2], Ruiz [34], and Padilla [35]. The amount of associated impurities within the concentrate, such as clay elements, pyrite, and silicas, among other compounds, can affect the overall analysis of the tests, which makes the experiment very unique based on its conditions. Finally, there are investigations carried out with white metal [31,36], which is an intermediate species that is formed in copper smelting furnaces that is mineralogically similar to chalcocite but does not have the same crystallographic behavior.

Table 1. Comparison with other investigations under similar conditions.

\begin{tabular}{|c|c|c|c|c|c|}
\hline Research Title & $\begin{array}{c}\text { Dissolution } \\
\text { Agents }\end{array}$ & Parameters Evaluated & Ref. & $\begin{array}{l}\text { Maximum Cu } \\
\text { Extraction }(\%)\end{array}$ & $\begin{array}{l}\text { Type of } \\
\text { Covellite }\end{array}$ \\
\hline $\begin{array}{l}\text { The kinetics of leaching } \\
\text { covellite in acidic } \\
\text { oxygenated } \\
\text { sulfate—chloride solutions }\end{array}$ & $\begin{array}{c}\mathrm{HCl}, \mathrm{HNO}_{3} \\
\mathrm{NaCl}, \mathrm{H}_{2} \mathrm{SO}_{4}\end{array}$ & $\begin{array}{l}\text { Temperature, oxygen } \\
\text { partial pressure, particle } \\
\text { size, stirring speed, and } \\
\text { sulfuric acid } \\
\text { concentration }\end{array}$ & [23] & $85 \%$ & $\begin{array}{c}\text { Synthetic } \\
\text { covellite }\end{array}$ \\
\hline $\begin{array}{l}\text { The kinetics of dissolution } \\
\text { of synthetic covellite, } \\
\text { chalcocite, and digenite in } \\
\text { dilute chloride solutions at } \\
\text { ambient temperatures }\end{array}$ & $\begin{array}{c}\mathrm{HCl}, \mathrm{Cu}^{2+} \text { and } \\
\mathrm{Fe}^{3+}\end{array}$ & $\begin{array}{l}\text { Potential effect, chloride } \\
\text { concentration, acid } \\
\text { concentration, } \\
\text { temperature, dissolved } \\
\text { oxygen, and pyrite effect }\end{array}$ & {$[24]$} & $>90 \%$ & $\begin{array}{c}\text { Synthetic } \\
\text { covellite }\end{array}$ \\
\hline
\end{tabular}

In this study, we leached pure covellite in a chloride medium with the incorporation of oxygen. This was performed at ambient temperature and pressure to determine the relevance of the sulfuric acid and sodium chloride concentration, followed by the dissolution time. The data were used to make a statistical analysis through a representative quadratic model of copper extraction.

\section{Materials and Methods}

\subsection{Covellite}

The covellite sample was obtained from a Michilla mine. Using a porcelain mortar, the sample (apparently pure) was reduced to a size between -150 and $+106 \mu \mathrm{m}$, and then these were chemically analyzed by atomic emission spectrometry via induction-coupled plasma (ICP-AES) in the geochemistry lab of the Geological Sciences Department of the Universidad Católica del Norte (Antofagasta, Chile). Table 2 shows the chemical composition of the experimental samples.

Table 2. Chemical analysis of the covellite ore.

\begin{tabular}{cccccc}
\hline Element & $\mathbf{C u}$ & $\mathbf{S}$ & $\mathbf{C a}$ & $\mathbf{O}$ & $\mathbf{H}$ \\
\hline Mass $(\%)$ & 56.14 & 31.08 & 3.66 & 8.76 & 0.36 \\
\hline
\end{tabular}

The mineralogical analysis is presented in Table 2, where the chemical species were identified by QEMSCAN (Bruker, Billerica, MA, USA). Covellite was the most abundant mineral (84.3\%), followed by a lower percentage of gypsum $(15.7 \%)$.

\subsection{Reagent and Leaching Tests}

The sulfuric acid of analytical grade was acquired from Merck, with a purity of 95-97\%, density of $1.84 \mathrm{~kg} / \mathrm{L}$, and molecular weight of $98.08 \mathrm{~g} / \mathrm{mol}$.

The leaching tests were carried out in a $50-\mathrm{mL}$ glass reactor with a $0.01 \mathrm{~S} / \mathrm{L}$ ratio of the leaching solution. A total of $200 \mathrm{mg}$ of covellite ore was maintained in agitation and suspension at $600 \mathrm{rpm}$ in a 
five-position magnetic stirrer (IKA ROS, CEP 13087-534, Campinas, Brazil) with an oxygen addition of $6 \mathrm{~mL} / \mathrm{min}$ connecting a hose to the reactor. The tests were realized at an ambient temperature (25 ${ }^{\circ} \mathrm{C}$ ), with variations of sulfuric acid and chloride concentrations and leaching time. The tests were performed in duplicate; chemical analyses were carried on $5 \mathrm{~mL}$ undiluted samples using atomic absorption spectrometry with a coefficient of variation $\leq 5 \%$ and a relative error between $5 \%$ and $10 \%$. Measurements of $\mathrm{pH}$ and oxidation-reduction potential (ORP) of PLS (pregnant leaching solution) were made using a pH-ORP meter (HANNA HI-4222, St. Louis, MO, USA). The solution ORP was measured in a combination ORP electrode cell composed of a platinum working electrode and a saturated $\mathrm{Ag} / \mathrm{AgCl}$ reference electrode.

\subsection{Experimental Design}

The $\mathrm{Cu}$ extraction rates was studied through the effects of time and chloride and $\mathrm{H}_{2} \mathrm{SO}_{4}$ concentrations variables on leaching covellite [37-40]. An experimental design was carried out considering three levels per factor, resulting in a total of 27 samples [41]. The fit of the multiple linear regression model was generated in the statistical software Minitab 18 (version 18, Pennsylvania State University, State College, PA, USA), studying the linear and quadratic effects and the interactions of the factors considered in the study [42], as shown in Equation (9).

The general form of the experimental model is represented by (Equation (9)):

$$
\begin{aligned}
\mathrm{Y}= & (\text { overall constant })+(\text { linear effects })+(\text { interaction effects })+(\text { curvature effects }) \\
& \mathrm{Y}=b_{0}+b_{1} x_{1}+b_{2} x_{2}+b_{3} x_{3}+b_{12} x_{1} x_{2}+b_{13} x_{1} x_{3}+b_{23} x_{2} x_{3}+b_{11} x_{1}^{2}+b_{22} x_{2}^{2}+b_{33} x_{3}^{2}
\end{aligned}
$$

where $b$ represents the variables coefficients and $x_{1}, x_{2}$, and $x_{3}$ are time, chloride, and $\mathrm{H}_{2} \mathrm{SO}_{4}$ concentration variables, respectively. Table 3 shows the parameters used in the experimental model, and Equation (10) shows the transformation between the real values $\left(Z_{i}\right)$ and coded values $\left(X_{i}\right)$ of the experimental design.

$$
X_{i}=\frac{Z_{i}-\frac{Z_{\text {high }}+Z_{\text {low }}}{2}}{\frac{Z_{\text {high }}-Z_{\text {low }}}{2}}
$$

where $Z_{\text {high }}$ and $Z_{\text {low }}$ are respectively the highest and lowest levels of each variable [43].

Table 3. Experimental parameters and codifications level.

\begin{tabular}{cccc}
\hline Experimental Variable & Low & Medium & High \\
\hline Time $(\mathrm{h})$ & 48 & 72 & 144 \\
Chloride Concentration $(\mathrm{g} / \mathrm{L})$ & 20 & 50 & 100 \\
$\mathrm{H}_{2} \mathrm{SO}_{4}$ Concentration $(\mathrm{M})$ & 0.5 & 1 & 2 \\
Codifications & -1 & 0 & 1 \\
\hline
\end{tabular}

The levels of selected parameters (Table 3) are justified by the following, starting with the level of chloride: at an industrial level, concentrations of up to $100 \mathrm{~g} / \mathrm{L}$ of chloride are being used to leach copper sulfides, while other researchers have indicated that the concentration of chloride does not have much relevance after $0.5 \mathrm{M}$ [23], which is equivalent to $18 \mathrm{~g} / \mathrm{L}$. That is why 20 to $100 \mathrm{~g} / \mathrm{L}$ was selected to evaluate its effect as a function of concentration. Meanwhile, something similar occurs with choice of the concentration of sulfuric acid. Some researchers have mentioned that its effect is minimal in the dissolution of copper from covellite; it is only necessary in small amounts. In the research of Cheng and Lawson [23], a significant change is not highlighted when the concentration of sulfuric acid was 0.5 or $2 \mathrm{M}$; therefore, these two values are chosen as limits to analyze their effect.

The $R^{2}, R^{2}$ adj, and $p$-values statistics were used to indicate whether the model obtained is adequate to describe the dependent variable under the sampled domain. The $R^{2}$ statistics measures the proportion of total variability that is explained by the model, the predicted $R^{2}$ statistic determines the performance 
of the model predicting the response, and finally, the $p$-values indicate whether there is a statistically significant association between the dependent variable and a determined independent variable [43].

\section{Results}

\subsection{ANOVA}

Based on the results obtained (Table 4). An ANOVA test (Table 5) showed no significant effect of the interaction $\{$ time, $\mathrm{Cl}$ \} and the effects of the curvature of chloride variable on the dependent variable (copper extraction). Meanwhile, the interactions between the effects $\left\{\right.$ Time, $\left.\mathrm{H}_{2} \mathrm{SO}_{4}\right\}$ and $\{$ Chloride, $\left.\mathrm{H}_{2} \mathrm{SO}_{4}\right\}$ and the curvature of time variable contribute to explain the variability of the model.

Table 4. Experimental configuration and $\mathrm{Cu}$ extraction data (at $\mathrm{T}=25^{\circ} \mathrm{C}$, Stirring rate $=600 \mathrm{rpm}, \mathrm{P}=1 \mathrm{~atm}$ ).

\begin{tabular}{|c|c|c|c|c|}
\hline Exp. No. & Time (h) & $\mathrm{Cl}(\mathrm{g} / \mathrm{L})$ & $\mathrm{H}_{2} \mathrm{SO}_{4}(\mathrm{M})$ & Cu Extraction Rate (\%) \\
\hline 1 & 48 & 20 & 0.5 & 2.50 \\
\hline 2 & 48 & 50 & 0.5 & 3.50 \\
\hline 3 & 48 & 100 & 0.5 & 6.00 \\
\hline 4 & 48 & 20 & 1 & 3.00 \\
\hline 5 & 48 & 50 & 1 & 3.63 \\
\hline 6 & 48 & 100 & 1 & 9.13 \\
\hline 7 & 48 & 20 & 2 & 3.25 \\
\hline 8 & 48 & 50 & 2 & 5.50 \\
\hline 9 & 48 & 100 & 2 & 11.38 \\
\hline 10 & 72 & 20 & 0.5 & 5.13 \\
\hline 11 & 72 & 50 & 0.5 & 8.75 \\
\hline 12 & 72 & 100 & 0.5 & 11.25 \\
\hline 13 & 72 & 20 & 1 & 5.88 \\
\hline 14 & 72 & 50 & 1 & 9.25 \\
\hline 15 & 72 & 100 & 1 & 13.88 \\
\hline 16 & 72 & 20 & 2 & 6.38 \\
\hline 17 & 72 & 50 & 2 & 11.63 \\
\hline 18 & 72 & 100 & 2 & 18.75 \\
\hline 19 & 144 & 20 & 0.5 & 24.63 \\
\hline 20 & 144 & 50 & 0.5 & 24.88 \\
\hline 21 & 144 & 100 & 0.5 & 28.75 \\
\hline 22 & 144 & 20 & 1 & 26.25 \\
\hline 23 & 144 & 50 & 1 & 29.75 \\
\hline 24 & 144 & 100 & 1 & 35.00 \\
\hline 25 & 144 & 20 & 2 & 28.75 \\
\hline 26 & 144 & 50 & 2 & 31.25 \\
\hline 27 & 144 & 100 & 2 & 38.75 \\
\hline
\end{tabular}

Table 5. ANOVA Cu extraction.

\begin{tabular}{ccc}
\hline Source & $\boldsymbol{F}$-Value & $\boldsymbol{p}$-Value \\
\hline Regression & 371.42 & 0.000 \\
Time & 2624.36 & 0.000 \\
$\mathrm{Cl}$ & 257.04 & 0.000 \\
$\mathrm{H}_{2} \mathrm{SO}_{4}$ & 105.5 & 0.000 \\
Time $\times$ Time & 9.7 & 0.006 \\
$\mathrm{Cl} \times \mathrm{Cl}$ & 0.56 & 0.466 \\
$\mathrm{H}_{2} \mathrm{SO}_{4} \times \mathrm{H}_{2} \mathrm{SO}_{4}$ & 3.39 & 0.083 \\
Time $\times \mathrm{Cl}$ & 0.81 & 0.379 \\
Time $\times \mathrm{H}_{2} \mathrm{SO}_{4}$ & 11.22 & 0.004 \\
$\mathrm{Cl} \times \mathrm{H}_{2} \mathrm{SO}_{4}$ & 22.6 & 0.000 \\
\hline
\end{tabular}


The contour plot in Figure 1 shows that the $\mathrm{Cu}$ extraction rate increases with more time and higher concentrations of chloride and $\mathrm{H}_{2} \mathrm{SO}_{4}$.

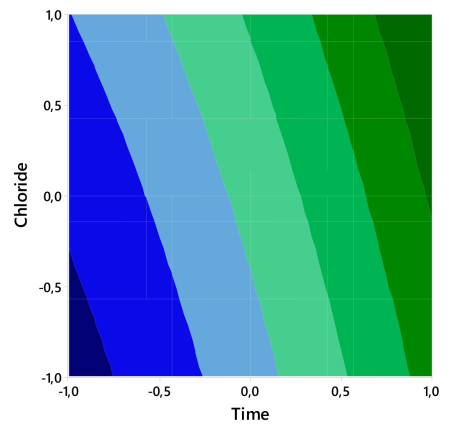

(a)
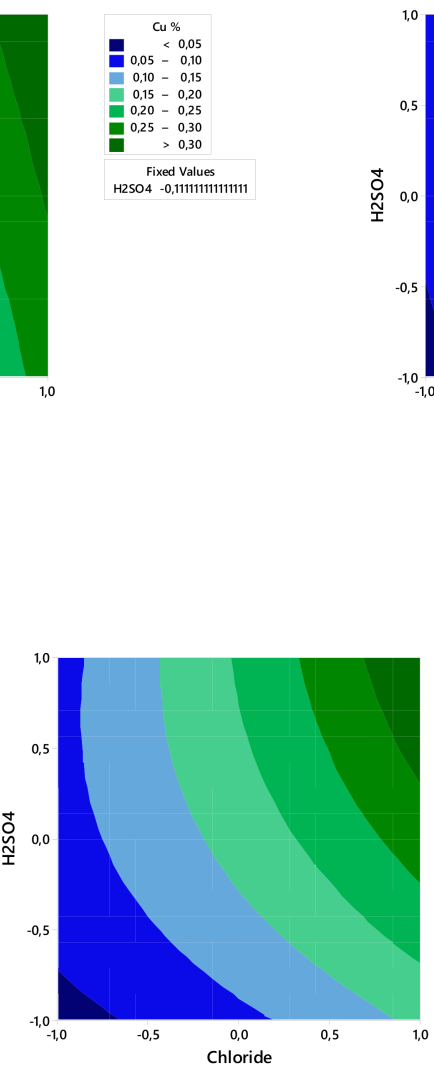

(c)

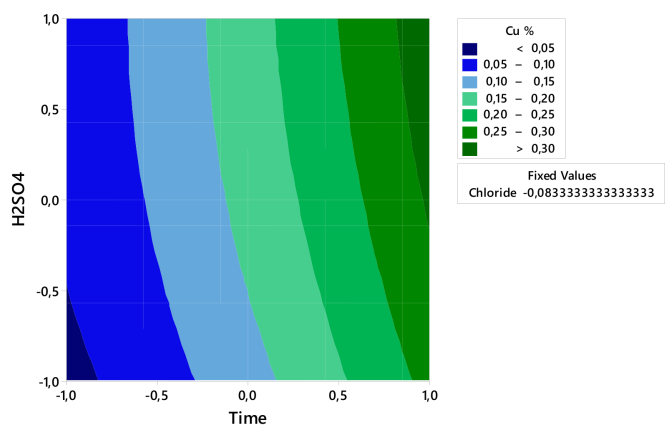

(b)

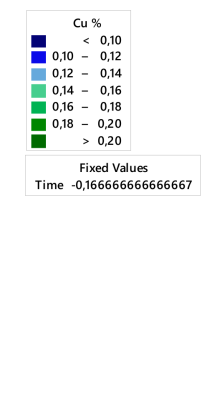

Figure 1. Experimental contour plot of $\mathrm{Cu}$ extraction versus time and chloride (a), time and $\mathrm{H}_{2} \mathrm{SO}_{4}$ concentration (b), and chloride concentration and $\mathrm{H}_{2} \mathrm{SO}_{4}$ concentration (c).

Figures 2 and 3 show that the linear effect of time, chloride, and $\mathrm{H}_{2} \mathrm{SO}_{4}$ concentration and the interactions of time- $\mathrm{H}_{2} \mathrm{SO}_{4}$ concentration and of chloride- $\mathrm{H}_{2} \mathrm{SO}_{4}$ concentrations affected the $\mathrm{Cu}$ extraction rate.

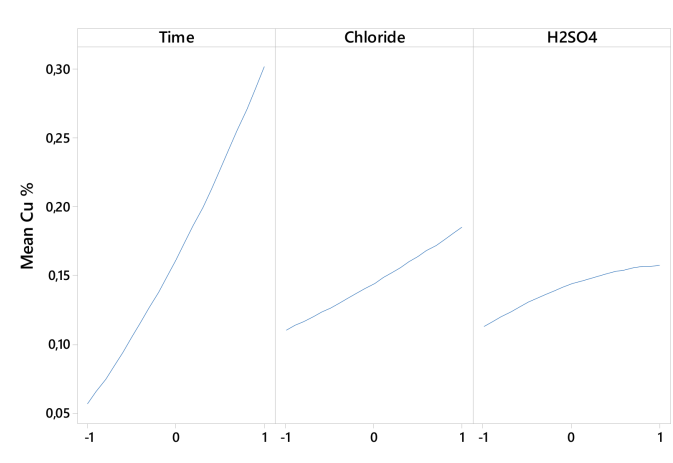

Figure 2. Linear effect plot for $\mathrm{Cu}$ extraction. 


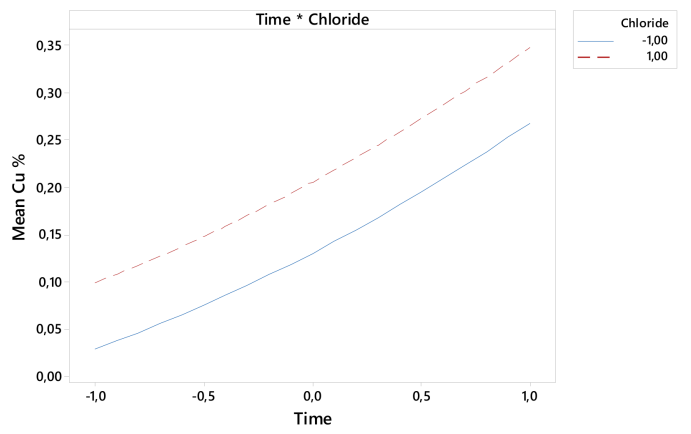

(a)

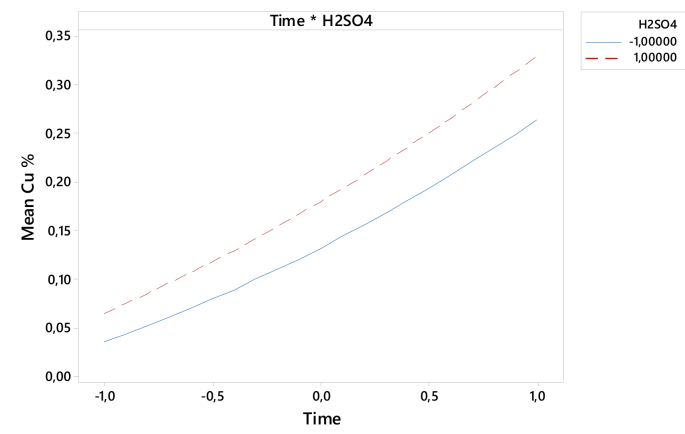

(b)

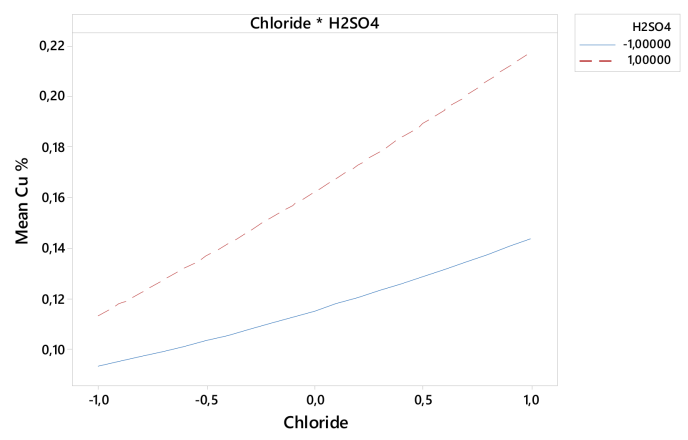

(c)

Figure 3. Interactions of time-chloride (a), time- $\mathrm{H}_{2} \mathrm{SO}_{4}$ concentration (b), and chloride- $\mathrm{H}_{2} \mathrm{SO}_{4}(\mathbf{c})$ on $\mathrm{Cu}$ extraction.

Then, the Cu extraction rate model over the range of sampled conditions is presented in Equation (11).

$$
\text { Cu Extraction } \begin{aligned}
(\%) & =0.16969+0.12332 x_{1}+0.03904 x_{2}+0.02502 x_{3}+0.01782 x_{1}^{2} \\
& -0.00870 x_{3}^{2}+0.00921 x_{1} x_{3}+0.01347 x_{2} x_{3}
\end{aligned}
$$

The ANOVA test indicated that the model presented in Equation (11) represents adequately the Cu extraction under the experimental domain, which is validated by the $R^{2}(0.9945)$ and $R^{2}$ adj values (0.9925). The ANOVA indicates that all the factors influence the $\mathrm{Cu}$ extraction from $\mathrm{CuS}$, as indicated in the $F$ statistic, where $F_{\text {reg }}(371.42)>F_{\mathrm{T}, 95 \%}$ confidence level $F_{7,19}(2.543)$. Additionally, the $p$-value was lower than the significance level, which indicates that the multiple regression is statistically significant.

The normality test applied to the standardized residuals of the regression model (Equation (11)) indicates that the residuals are relatively close to the fitted normal distribution line (Figure 4), and the $p$-value of the test is greater than the significance level (0.05), so it is not possible to reject the assumption that the model residuals are normally distributed.

Finally, the ANOVA analysis indicated that the independent variables considered can explain the variations in the copper extraction, the minimal difference between $R^{2}$ and $R^{2}$ pred reduces the possibility that the model is over-adjusted, and the leaching, chloride, and $\mathrm{H}_{2} \mathrm{SO}_{4}$ concentrations, and the interactions of time- $\mathrm{H}_{2} \mathrm{SO}_{4}$ and chloride- $\mathrm{H}_{2} \mathrm{SO}_{4}$ are the most critical factors in explaining the process. 


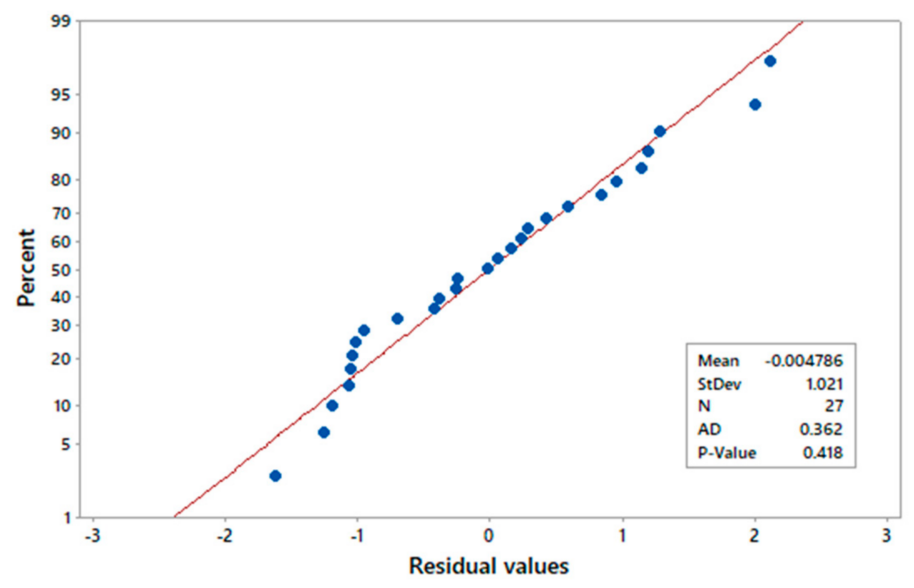

Figure 4. Probability plot of residual values.

\subsection{Effect of Chloride Concentration}

Figure 5 shows that the highest rate of copper extraction (71.2\%) was obtained with high concentrations of chloride ions $(100 \mathrm{~g} / \mathrm{L})$, demonstrating the importance of this variable [4,24]. However, Cheng and Lawson [23] stated that over a critical chloride concentration at $0.25 \mathrm{M}$, there is no more significant influence of the electrolyte. In the range of 20 to $50(\mathrm{~g} / \mathrm{L})$, chloride has no positive effects based on the leaching time, obtaining maximum copper extractions of $44.9 \%$ and $56.3 \%$, respectively. This agrees with the results of other research [24], which indicates that CuS oxidation to $\mathrm{CuS}_{2}$ is possible with any chloride concentration, but the oxidation of $\mathrm{CuS}_{2}$ is only possible with very high potential or high chloride concentrations [25].

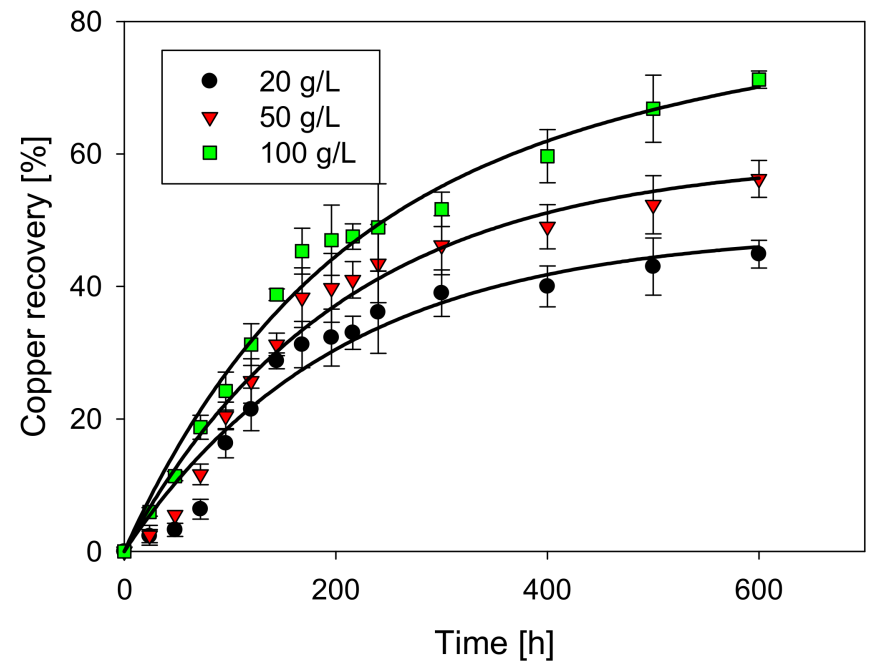

Figure 5. Extraction of $\mathrm{Cu}(\%)$ vs. time (h), depending on the addition of chloride.

\section{Conclusions}

The present research shows the laboratory results of dissolving copper from covellite in chloride media provided by $\mathrm{NaCl}$. The highest copper extraction rate was obtained with the highest concentrations of chloride, and the main findings of this investigation were:

1. The linear variables of time and chloride concentration have the greatest influence on the model.

2. Under ambient conditions of pressure and temperature, $\mathrm{H}_{2} \mathrm{SO}_{4}$ concentration-time and chloride concentration-time have significant effects on copper extraction kinetics from covellite. 
3. The ANOVA analysis indicates that the quadratic model adequately represents copper extraction, which was validated by the $R^{2}$ value (0.9945).

4. The highest copper extraction rate at ambient temperature of $71.2 \%$ was obtained with a low sulfuric acid concentration $(0.5 \mathrm{M})$, high level of chloride $(100 \mathrm{~g} / \mathrm{L})$, and extended leaching time (600 h).

Author Contributions: K.P., N.T., R.I.J. contributed in project administration, investigation and wrote paper, M.S. and D.T. contributed in the data curation, E.S.-R. and P.R. contributed in validation and supervision. All authors have read and agreed to the published version of the manuscript.

Funding: This research received no external funding.

Acknowledgments: The authors are grateful for the contribution of the Scientific Equipment Unit-MAINI of the Universidad Católica del Norte for facilitating the chemical analysis of the solutions. Pedro Robles thanks the Pontificia Universidad Católica de Valparaíso for the support provided. Also, we thank Conicyt Fondecyt 11171036 and Centro CRHIAM Project Conicyt/Fondap/15130015.

Conflicts of Interest: The authors declare they have no conflict of interest.

\section{References}

1. Klein, C.; Hurlbut, C.S. Manual de Mineralogía; Reverté: Madrid, Spain, 1996; ISBN 8429146067.

2. Lundström, M.; Liipo, J.; Taskinen, P.; Aromaa, J. Copper precipitation during leaching of various copper sulfide concentrates with cupric chloride in acidic solutions. Hydrometallurgy 2016, 166, 136-142. [CrossRef]

3. Ruiz, M.C.; Honores, S.; Padilla, R. Leaching kinetics of digenite concentrate in oxygenated chloride media at ambient pressure. Metall. Mater. Trans. B 1998, 29, 961-969. [CrossRef]

4. Senanayake, G. Chloride assisted leaching of chalcocite by oxygenated sulphuric acid via $\mathrm{Cu}(\mathrm{II})-\mathrm{OH}-\mathrm{Cl}$. Miner. Eng. 2007, 20, 1075-1088. [CrossRef]

5. Schlesinger, M.E.; King, M.J.; Sole, K.C.; Davenport, W.G. Extractive Metallurgy of Copper, 5th ed.; Elsevier: Oxford, UK, 2011; ISBN 9780080967899.

6. Shuva, M.A.H.; Rhamdhani, M.A.; Brooks, G.A.; Masood, S.; Reuter, M.A. Thermodynamics data of valuable elements relevant to e-waste processing through primary and secondary copper production: A review. J. Clean. Prod. 2016, 131, 795-809. [CrossRef]

7. Turan, M.D.; Sari, Z.A.; Miller, J.D. Leaching of blended copper slag in microwave oven. Trans. Nonferrous Met. Soc. China 2017, 27, 1404-1410. [CrossRef]

8. Kelm, U.; Avendaño, M.; Balladares, E.; Helle, S.; Karlsson, T.; Pincheira, M. The use of water-extractable $\mathrm{Cu}, \mathrm{Mo}, \mathrm{Zn}, \mathrm{As}, \mathrm{Pb}$ concentrations and automated mineral analysis of flue dust particles as tools for impact studies in topsoils exposed to past emissions of a Cu-smelter. Chemie der Erde 2014, 74, 365-373. [CrossRef]

9. Afif, C.; Chélala, C.; Borbon, A.; Abboud, M.; Adjizian-Gérard, J.; Farah, W.; Jambert, C.; Zaarour, R.; Saliba, N.B.; Perros, P.E.; et al. $\mathrm{SO}_{2}$ in Beirut: Air quality implication and effects of local emissions and long-range transport. Air Qual. Atmos. Heal. 2008, 1, 167-178. [CrossRef]

10. Dijksira, R.; Senyard, B.; Shah, U.; Lee, H. Economical abatement of high-strength $\mathrm{SO}_{2}$ off-gas from a smelter. J. South. African Inst. Min. Metall. 2017, 117, 1003-1007. [CrossRef]

11. Dimitrijević, M.; Kostov, A.; Tasić, V.; Milosević, N. Influence of pyrometallurgical copper production on the environment. J. Hazard. Mater. 2009, 164, 892-899. [CrossRef]

12. Sánchez de la Campa, A.M.; de la Rosa, J.D.; Sánchez-Rodas, D.; Oliveira, V.; Alastuey, A.; Querol, X.; Gómez Ariza, J.L. Arsenic speciation study of PM2.5 in an urban area near a copper smelter. Atmos. Environ. 2008, 42, 6487-6495. [CrossRef]

13. Serbula, S.M.; Milosavljevic, J.S.; Radojevic, A.A.; Kalinovic, J.V.; Kalinovic, T.S. Extreme air pollution with contaminants originating from the mining-Metallurgical processes. Sci. Total Environ. 2017, 586, 1066-1075. [CrossRef] [PubMed]

14. Balladares, E.; Jerez, O.; Parada, F.; Baltierra, L.; Hernández, C.; Araneda, E.; Parra, V. Neutralization and co-precipitation of heavy metals by lime addition to effluent from acid plant in a copper smelter. Miner. Eng. 2018, 122, 122-129. [CrossRef]

15. World Health Organization. World Health Statistics 2018: Monitoring Health for the SDGs, Sustainable Development Goals; WHO: Geneva, Switzerland, 2018; ISBN 9789241565585. 
16. Baba, A.A.; Balogun, A.F.; Olaoluwa, D.T.; Bale, R.B.; Adekola, F.A.; Alabi, A.G.F. Leaching kinetics of a Nigerian complex covellite ore by the ammonia-ammonium sulfate solution. Korean J. Chem. Eng. 2017, 34, 1133-1140. [CrossRef]

17. González, C.; Parra, R.; Klenovcanova, A.; Imris, I.; Sánchez, M. Reduction of Chilean copper slags: A case of waste management project. Scand. J. Metall. 2005, 34, 143-149. [CrossRef]

18. Lü, C.; Wang, Y.; Qian, P.; Liu, Y.; Fu, G.; Ding, J.; Ye, S.; Chen, Y. Separation of chalcopyrite and pyrite from a copper tailing by ammonium humate. Chinese J. Chem. Eng. 2018, 26, 1814-1821. [CrossRef]

19. Rabadjieva, D.; Tepavitcharova, S.; Todorov, T.; Dassenakis, M.; Paraskevopoulou, V.; Petrov, M. Chemical speciation in mining affected waters: The case study of Asarel-Medet mine. Environ. Monit. Assess. 2009, 159, 353-366. [CrossRef]

20. Reilly, I.G.; Scott, D.S. The leaching of cupric sulfide in ammonia. Ind. Eng. Chem. Process Des. Dev. 1976, 15, 60-67. [CrossRef]

21. Fisher, W.W. Comparison of chalcocite dissolution in the sulfate, perchlorate, nitrate, chloride, ammonia, and cyanide systems. Miner. Eng. 1994, 7, 99-103. [CrossRef]

22. Vračar, R.Ž.; Vučković, N.; Kamberović, Ž. Leaching of copper(I) sulphide by sulphuric acid solution with addition of sodium nitrate. Hydrometallurgy 2003, 70, 143-151. [CrossRef]

23. Cheng, C.Y.; Lawson, F. The kinetics of leaching covellite in acidic oxygenated sulphate-chloride solutions. Hydrometallurgy 1991, 27, 249-268. [CrossRef]

24. Miki, H.; Nicol, M.; Velásquez-Yévenes, L. The kinetics of dissolution of synthetic covellite, chalcocite and digenite in dilute chloride solutions at ambient temperatures. Hydrometallurgy 2011, 105, 321-327. [CrossRef]

25. Nicol, M.; Basson, P. The anodic behaviour of covellite in chloride solutions. Hydrometallurgy 2017, 172, 60-68. [CrossRef]

26. Donati, E.; Pogliani, C.; Boiardi, J.L. Anaerobic leaching of covellite by Thiobacillus ferrooxidans. Appl. Microbiol. Biotechnol. 1997, 47, 636-639. [CrossRef]

27. Monteiro, F.V.; Garcia, O.; Tuovinen, O. Oxidative dissolution of covellite by Thiobacillus ferrooxidans. Process Metall. 1999, 9, 283-290.

28. Falco, L.; Pogliani, C.; Curutchet, G.; Donati, E. A comparison of bioleaching of covellite using pure cultures of Acidithiobacillus ferrooxidans and Acidithiobacillus thiooxidans or a mixed culture of Leptospirillum ferrooxidans and Acidithiobacillus thiooxidans. Hydrometallurgy 2003, 71, 31-36. [CrossRef]

29. Lee, J.; Acar, S.; Doerr, D.L.; Brierley, J.A. Comparative bioleaching and mineralogy of composited sulfide ores containing enargite, covellite and chalcocite by mesophilic and thermophilic microorganisms. Hydrometallurgy 2011, 105, 213-221. [CrossRef]

30. Niu, X.; Ruan, R.; Tan, Q.; Jia, Y.; Sun, H. Study on the second stage of chalcocite leaching in column with redox potential control and its implications. Hydrometallurgy 2015, 155, 141-152. [CrossRef]

31. Ruiz, M.C.; Abarzúa, E.; Padilla, R. Oxygen pressure leaching of white metal. Hydrometallurgy 2007, 86, 131-139. [CrossRef]

32. Senanayake, G. A review of chloride assisted copper sulfide leaching by oxygenated sulfuric acid and mechanistic considerations. Hydrometallurgy 2009, 98, 21-32. [CrossRef]

33. Ruan, R.; Zou, G.; Zhong, S.; Wu, Z.; Chan, B.; Wang, D. Why Zijinshan copper bioheapleaching plant works efficiently at low microbial activity-Study on leaching kinetics of copper sulfides and its implications. Miner. Eng. 2013, 48, 36-43. [CrossRef]

34. Ruiz, M.C.; Montes, K.S.; Padilla, R. Chalcopyrite leaching in sulfate-chloride media at ambient pressure. Hydrometallurgy 2011, 109, 37-42. [CrossRef]

35. Padilla, R.; Jerez, O.; Ruiz, M.C. Hydrometallurgy Kinetics of the pressure leaching of enargite in $\mathrm{FeSO}_{4}-\mathrm{H}_{2} \mathrm{SO}_{4}-\mathrm{O}_{2}$ media. Hydrometallurgy 2015, 158, 49-55. [CrossRef]

36. Ruiz, M.C.; Gallardo, E.; Padilla, R. Copper extraction from white metal by pressure leaching in H2SO4-FeSO4-O2. Hydrometallurgy 2009, 100, 50-55. [CrossRef]

37. Aguirre, C.L.; Toro, N.; Carvajal, N.; Watling, H.; Aguirre, C. Leaching of chalcopyrite $\left(\mathrm{CuFeS}_{2}\right)$ with an imidazolium-based ionic liquid in the presence of chloride. Miner. Eng. 2016, 99, 60-66. [CrossRef]

38. Bezerra, M.A.; Santelli, R.E.; Oliveira, E.P.; Villar, L.S.; Escaleira, L.A. Response surface methodology (RSM) as a tool for optimization in analytical chemistry. Talanta 2008, 76, 965-977. [CrossRef]

39. Dean, A.; Voss, D.; Draguljic, D. Response Surface Methodology. In Design and Analysis of Experiments; Springer Nature: Cham, Switzerland, 2017; pp. 565-614. 
40. Toro, N.; Herrera, N.; Castillo, J.; Torres, C.; Sepúlveda, R. Initial investigation into the leaching of manganese from nodules at room temperature with the use of sulfuric acid and the addition of foundry slag-Part I. Minerals 2018, 8, 565. [CrossRef]

41. Toro, N.; Saldaña, M.; Gálvez, E.; Cánovas, M.; Trigueros, E.; Castillo, J.; Hernández, P.C. Optimization of parameters for the dissolution of $\mathrm{mn}$ from manganese nodules with the use of tailings in an acid medium. Minerals 2019, 9, 387. [CrossRef]

42. Saldaña, M.; Toro, N.; Castillo, J.; Hernández, P.; Trigueros, E.; Navarra, A. Development of an analytical model for the extraction of manganese from marine nodules. Metals 2019, 9, 903. [CrossRef]

43. Montgomery, D.C. Design and Analysis of Experiments; John Wiley \& Sons: New York, NY, USA, 2012.

(C) 2020 by the authors. Licensee MDPI, Basel, Switzerland. This article is an open access article distributed under the terms and conditions of the Creative Commons Attribution (CC BY) license (http://creativecommons.org/licenses/by/4.0/). 